Miguel A Sánchez-Alemán

Carlos J Conde-Glez

Felipe Uribe-Salas

\section{Core group approach to identify college students at risk for sexually transmitted infections}

\author{
"Core group" para identificar \\ universitários em risco para \\ infecções sexualmente transmissíveis
}

Centro de Investigaciones sobre Enfermedades Infecciosas. Instituto Nacional de Salud Pública. Cuernavaca, Morelos, México

\section{Correspondence:}

Felipe Uribe-Salas

Centro de Investigaciones sobre Enfermedades Infecciosas

Instituto Nacional de Salud Pública.

Av. Universidad 655, Col. Sta. Ma.

Ahuacatitlán

CP 62508 Cuernavaca, Morelos, México

E-mail: fjuribe@correo.insp.mx

\section{ABSTRACT}

OBJECTIVE: To analyze the core group for sexually transmitted infections (STI) among college students.

METHODS: Cross-sectional study carried out in a convenience sample comprising 711 college students of the public university of Morelos, Mexico, between 2001 and 2003. Sociodemographic and sexual behavior information were collected using self-applied questionnaires. Herpes simplex 2 (HSV-2) infection was tested in the blood. The number of sexual partners in the last year and cocaine consumption were used as indicators to construct the dependent variable "level of STI risk" in three categories: low, medium and high risk (core group). A multinomial analysis was conducted to evaluate whether different sex behaviors were associated with the variable "level of STI risk".

RESULTS: There was significant association between HSV-2 seroprevalence and the variable "level of STI risk": $13 \%, 5.6 \%$ and $3.8 \%$ were found in high (core group), medium and low categories, respectively. There were gender differences regarding the core group. Men started having sexual intercourse earlier, had more sex partners, higher alcohol and drug consumption, higher frequency of sex intercourse with sex workers, exchanging sex for money, occasional and concurrent partners compared to women.

CONCLUSIONS: The study findings suggest existing contextual characteristics in the study population that affect their sex behavior. In Mexico, the cultural conception of sexuality is determined mainly by gender differences where men engage in higher risky sexual behavior than women.

DESCRIPTORS: Students. Sexually Transmitted Diseases, prevention \& control. Sexual Behavior. Risk Factors. Socioeconomic Factors. Cross-Sectional Studies. 


\section{RESUMO}

OBJETIVO: Analisar o core group em estudantes universitários em risco de adquirir infecções sexualmente transmissíveis (IST).

MÉTODOS: Estudo transversal com amostra de conveniência composta por 711 estudantes de universidade pública de Morelos, no México, 2001-2003. Informações sociodemográficas e de comportamento sexual foram coletadas por meio de questionário auto-aplicável. Presença de infecção por Herpes simplex 2 foi diagnosticada por exame de sangue. O número de parceiros sexuais durante o último ano anterior à pesquisa e o consumo de cocaína foram indicadores utilizados para construir a variável dependente "nível de risco para adquirir IST" e definir três categorias: baixo, médio e alto risco (core group). Foi utilizada análise multinominal para avaliar se diferentes comportamentos sexuais estavam associados à variável "nível de risco para adquirir IST".

RESULTADOS: Houve associação significativa entre a soroprevalência de HSV-2 e a variável "nível de risco para adquirir IST" nas categorias de alto $(13 \%)$, médio $(5,6 \%)$ e baixo $(3,8 \%)$ risco. Foram encontradas diferenças entre os sexos em relação ao core group. Em comparação às mulheres, os homens começaram a ter relações sexuais mais cedo, tiveram maior número de parceiras sexuais, níveis mais elevados de consumo de álcool e drogas, maior freqüência de sexo com profissionais do sexo, prática de sexo por dinheiro, parceiras ocasionais e concomitantes.

CONCLUSÕES: Os resultados sugerem a existência de características contextuais da população que influenciam o comportamento sexual. No México, a concepção cultural de sexualidade é caracterizada por diferenças marcantes entre homens e mulheres, nas quais os homens têm comportamento sexual de maior risco que as mulheres.

DESCRITORES: Estudantes. Doenças Sexualmente Transmissíveis, prevenção e controle. Comportamento Sexual. Fatores de Risco. Fatores Socioeconômicos. Estudos Transversais.

\section{INTRODUCTION}

Different conceptual frameworks have been developed to describe the propagation of an infectious agent among people. ${ }^{13}$ In regard to sexually transmitted infections (STI), the epidemiological notion of sexual spread of an infectious agent has been borrowed from the concept of population ecology, which describes the number of new infections generated by a given infection. ${ }^{1,12}$ The description of disease propagation based on population ecology contributed to the notion that the interaction of groups at differing levels of risk can be used to study transmission. Yorke et $\mathrm{al}^{23}$ were the first to observe that gonorrhea was nonrandomly distributed in the US population. They found that the population is quite heterogeneous, formed by groups according to age, sex, sexual behavior, geographic location, and socioeconomic status, and then they divided them into two groups based on frequency of new sexual encounters and defined a core group consisting of individuals who were very sexually active and efficient transmitters of gonorrhea. According to those authors, the core group was ten-times as sexually active as non-core members, but represented only $2 \%$ of the population. As a result, a small core group was shown to have a significant role in the spread of gonorrhea.

Further development of the core group concept has taken different definitions as Thomas \& Tucker pointed out. ${ }^{18}$ Despite great controversy regarding different definitions of the term "core group," some authors consider that this concept "works well as a unitary component whose contents remain unspecified". ${ }^{15}$ In this sense, the core group is a theoretical concept which can be used to explain the reproductive rate of an STI within a population, but the problem appears when translating the model into practice because STI transmitters are difficult to identify as individuals belonging to specific groups. More recently, some authors have taken different approaches for the implementation of core group research. ${ }^{3,21}$ 
The seroprevalence of Herpes simplex virus type 2 (HSV-2) and its association to sexual behavior among college students was studied in Mexico. ${ }^{16}$ Low HSV2 seroprevalence was found among college students $(5.9 \%)$ compared to that reported in other population groups in Mexico. ${ }^{7,19,24}$ However, certain characteristics related to sexual behavior such as exchanging sex for money, having a high number of sexual partners and differences between males and females sex behavior supported the hypothesis of an existing core group comprising mostly men, which could be playing an important role in the spread of this infection inside or outside college students. ${ }^{16}$ The basic idea of studying a hypothetical core group in this study was not to identify specific social groups but rather recognize those individuals who have multiple sexual partners and the highest prevalence of HSV-2 infection and who are potential STI transmitters to susceptible populations. The objective of the present study was to analyze college students at risk of acquiring STIs.

\section{METHODS}

A dynamic cohort of students was constructed to estimate the incidence of HSV-2 infection in a public state university of Morelos, Mexico. This construction was based on a cross-sectional survey. A total of 711 sexually active students - 419 women $(58.9 \%)$ and 292 men $(41.1 \%)$ - were recruited between 2001 and 2003 through convenience sampling in the schools of Administration, Biology, Medicine, Education, Law, Pharmacy and Psychology. The strategy used to approach the university authorities and students is described elsewhere. ${ }^{16}$

Subjects answered a self-applied questionnaire on sociodemographic characteristics, drug consumption and sexual behavior. The students' age distribution was categorized into three groups (18-20 years old, 21-22 years old and $\geq 23$ years old). Age at first sexual intercourse was classified into two categories: 10-16 years old and $\geq 17$. Likewise, the variable on how long subjects had known their first sexual partner before having intercourse was constructed and divided into two categories: $<1$ month and $\geq 1$ month. The variable alcohol intake was considered the frequency of consumption: high consumption (those who drank alcohol at least once a week and up to once a day); medium consumption included those who consumed alcohol at least six times a year and up to three times a month; and low consumption included those who did not consume alcohol. The variable smoking included those who had smoked more than 100 cigarettes during their lifetime. ${ }^{22}$ Variables such as sexual intercourse with commercial sex workers, same-sex practices, casual partners, exchanging sex for money and concurrent partners were structured as dichotomous variables. Consistent condom use was defined as condom use during the first and last sexual intercourse. The variable drug consumption was assessed based on marijuana and/or cocaine use at least once.

The following variables were used to identify the hypothetical core group: number of sexual partners over the last year and cocaine use. The first variable was categorized into two strata by using the upper quartile $(>75 \%)$ to separate both strata, according to the theoretical distribution of the number of sexual partners among the population at large. ${ }^{6}$ The variable "cocaine use" was used because it has been reported as significantly linked to risky sexual behavior ${ }^{11}$ and network characteristics among young people. ${ }^{9}$

All subjects gave $10 \mathrm{~mL}$ of blood by venipuncture. Specific antibodies against HSV-2 were detected by the Western blot technique using a recombinant baculovirus which expresses the gG2 protein of HSV-2 following infection of Sf-9 insect cells. ${ }^{17}$

The new variable called "level of STI risk" was classified as follows: high risk (core group), which included subjects with a high number of sexual partners (those in the upper quartile of sex partner distribution) and who had consumed cocaine; medium risk, which included those with a high number of sex partners or who had consumed cocaine; and low risk, which included subjects with a low number of sex partners and who had not consumed cocaine. The variable of interest was validated by its association with seroprevalence of specific antibodies against HSV-2. This last variable represents a biological marker that has been related to sexual lifestyle at population level. ${ }^{8}$

A bivariate analysis was performed considering "level of risk" as a dependent variable and sociodemographic characteristics, drug consumption, sexual behavior and seroprevalence of HSV-2 infection as independent variables. In order to establish the magnitude of the association, odds ratios and their corresponding confidence intervals were estimated. Multivariate regression analysis was conducted using a multinomial model. In this analysis it is assumed three outcomes regarding the dependent variable and two logistic functions are carried out taking one of the outcomes as reference. ${ }^{4}$ It was analyzed whether the characteristics of those in the high-risk group (reference) are different from those in medium- and low-risk groups. A backward method was used for variable selection and those with p-value higher than 0.05 were excluded. Variables such as smoking and concurrent partners were kept in the women's model as it was important to compare them with the corresponding variables in the men's model. Due to the high prevalence of the outcomes to be compared regarding the "level of risk" variable, particularly that in the medium-risk (25\%) and low-risk group $(70.8 \%)$, a method was applied to correct the overestimation of odds ratios obtained in the bivariate and multivariate analyses. ${ }^{25}$ 
The research protocol was approved by the Institutional Review Board of the Instituto Nacional de Salud Pública (National Institute of Public Health) in Mexico, and the students who agreed to participate in the study signed an informed consent form.

\section{RESULTS}

The variable "level of STI risk" had the following distribution: 4\% ( $\mathrm{N}=29), 25 \%(\mathrm{~N}=178)$ and $70.8 \%$ $(\mathrm{N}=504)$ in the high-, medium- and low-risk categories, respectively. Men reported a higher number of sex partners than women during their lifetime (4.7 versus $2.3, \mathrm{p}<0.001)$ and over the last year (1.6 versus $1.2, \mathrm{p}=0.001)$. On average, men started having sexual intercourse earlier than women (16.9 years versus 18.2 years, $\mathrm{p}<000.1)$ and at a younger first sexual partners age (18.4 years versus 21.1 years, $p<0.001$ ). No differences were found between men and women regarding age, smoking, condom use and same-sex practices. However, men consumed more alcohol and drugs than women $(21.9 \%$ versus $10 \%, \mathrm{p}<0.001$ and $27.1 \%$ versus $14.3 \%, \mathrm{p}<0.001$, respectively). Men reported more sexual intercourse with sex workers (13.1\% versus $0.2 \%, p<0.001)$, exchanging sex for money $(3.8 \%$ versus $0.7 \%, p=0.005)$, casual partners $(42.3 \%$ versus $14.6 \%, \mathrm{p}<0.001)$ and concurrent partners $(23 \%$ versus $11 \%, \mathrm{p}<0.001)$.

There was a significant association between HSV-2 seroprevalence and "level of STI risk". The magnitude of the associations were 4.1 (95\% CI: $1.3 ; 12.9)$ and 2.7 (95\% CI: 0.8;9.3) times higher among those in the high-risk group compared to those in low- and medium-risk groups, respectively (Table 1). After stratifying by gender, there were no cases of HSV-2 infection among women in the high-risk group. For men, however, the magnitude of the associations were 11 (95\% CI: 2.5;48.5) and 6.7 (95\% CI: 1.5;29.5) times higher than that seen in the low- and medium-risk groups, respectively.

The bivariate analysis was stratified by gender. Among men, those in the high-risk group were more likely to have had their first intercourse within one month of meeting their partner, same-sex practices, concurrent partners and higher HSV-2 seroprevalence compared to those in the medium-risk group (Table 2). Those in the high-risk group were also more likely to have had their first sexual intercourse under the age of 16, sex with commercial workers, exchanging sex for money, concurrent and casual partners and higher HSV-2 seroprevalence compared to men in the low-risk group.

Women in the high-risk group were more likely to have the following behavior compared to women in the other two categories: high alcohol consumption and casual partners. The likelihoods of smoking and having had concurrent partners were significantly higher among those in the high-risk group compared to those in the low-risk group (Table 3).

In the multivariate analysis, the probabilities of high alcohol consumption and history of casual partners were significantly higher among those female students in the high-risk group compared to those in the medium- and low-risk groups (Table 4). Among men, the probability of smoking, having had their first sexual relationship under the age of 16 , first intercourse within one month of meeting partner, same-sex practices, concurrent partners and being HSV-2 seropositive were significantly higher among those in the high-risk group compared to those in the low-risk group. Likewise, the probability of smoking, first intercourse within one month of meeting partner, same-sex practices and being HSV-2 seropositive were significantly higher among those in the high-risk group compared to those in the mediumrisk group (Table 4).

Table 1. Association between the "level of STI risk" and HSV-2 seroprevalence in college students. Morelos, Mexico, 2001-2003.

\begin{tabular}{|c|c|c|c|c|c|c|c|c|}
\hline \multirow{2}{*}{ Characteristic } & \multicolumn{2}{|c|}{ High-risk } & \multicolumn{2}{|c|}{ Medium-risk } & \multicolumn{2}{|c|}{ Low-risk } & \multirow{2}{*}{$\begin{array}{l}\text { High vs. medium* } \\
\text { OR }(95 \% \mathrm{Cl})\end{array}$} & \multirow{2}{*}{$\begin{array}{l}\text { High vs. low* } \\
\text { OR }(95 \% \mathrm{Cl})\end{array}$} \\
\hline & $\mathrm{N}$ & $\%$ & $\mathrm{~N}$ & $\%$ & $\mathrm{~N}$ & $\%$ & & \\
\hline \multicolumn{9}{|l|}{ Total } \\
\hline Seropositive & 4 & 13.8 & 10 & 5.6 & 20 & 4.0 & $2.7(0.8 ; 9.3)$ & $4.1(1.3 ; 12.9)$ \\
\hline Seronegative & 25 & 86.2 & 168 & 94.4 & 484 & 96.0 & 1.0 & 1.0 \\
\hline \multicolumn{9}{|l|}{ Women } \\
\hline Seropositive & 0 & 0.0 & 6 & 8.1 & 16 & 4.8 & - & - \\
\hline Seronegative & 10 & 100.0 & 68 & 91.9 & 319 & 95.2 & & \\
\hline \multicolumn{9}{|l|}{ Men } \\
\hline Seropositive & 4 & 21.1 & 4 & 3.8 & 4 & 2.4 & $6.7(1.5 ; 29.5)$ & $11.0(2.5 ; 48.5)$ \\
\hline Seronegative & 15 & 78.9 & 100 & 96.2 & 165 & 97.6 & 1.0 & 1.0 \\
\hline
\end{tabular}

* Based on a correction method

STI: sexually transmitted infection

HSV-2: Herpes simplex virus type 2 
Table 2. Relationship between "level of STI risk" and sociodemographic characteristics, sexual behavior and HSV-2 seroprevalence in male students. Morelos, Mexico, 2001-2003.

\begin{tabular}{|c|c|c|c|c|c|c|c|c|}
\hline \multirow{2}{*}{ Characteristic } & \multicolumn{2}{|c|}{ High-risk } & \multicolumn{2}{|c|}{ Medium-risk } & \multicolumn{2}{|c|}{ Low-risk } & \multirow{2}{*}{$\begin{array}{l}\text { High vs. medium* } \\
\text { OR }(95 \% \mathrm{Cl})\end{array}$} & \multirow{2}{*}{$\begin{array}{c}\text { High vs. low** } \\
\text { OR }(95 \% \mathrm{Cl})\end{array}$} \\
\hline & $\mathrm{N}$ & $\%$ & $\mathrm{~N}$ & $\%$ & $\mathrm{~N}$ & $\%$ & & \\
\hline \multicolumn{9}{|l|}{ Age (years) } \\
\hline$\geq 23$ & 8 & 42.1 & 35 & 34.0 & 62 & 36.7 & $1.5(0.7 ; 2.2)$ & $1.5(0.7 ; 2.3)$ \\
\hline $21-22$ & 7 & 36.8 & 33 & 32.0 & 37 & 21.9 & $2.2(0.9 ; 3.5)$ & $1.5(0.6 ; 2.4)$ \\
\hline $18-20$ & 4 & 21.1 & 35 & 34.0 & 70 & 41.4 & 1.0 & 1.0 \\
\hline \multicolumn{9}{|l|}{ Smoking } \\
\hline Sometimes & 18 & 94.7 & 62 & 59.6 & 79 & 46.7 & $1.6(1.2 ; 1.7)$ & $2.0(1.5 ; 2.1)$ \\
\hline Never & 1 & 5.3 & 42 & 40.4 & 90 & 53.3 & 1.0 & 1.0 \\
\hline \multicolumn{9}{|c|}{ Alcohol consumption } \\
\hline High & 10 & 52.6 & 32 & 30.8 & 22 & 8.3 & $1.7(0.9 ; 2.4)$ & $4.0(2.2 ; 5.8)$ \\
\hline Medium/low & 9 & 47.4 & 72 & 69.2 & 147 & 91.7 & 1.0 & 1.0 \\
\hline \multicolumn{9}{|c|}{ First sexual relationship } \\
\hline 10-16 years & 13 & 68.4 & 48 & 46.6 & 51 & 30.2 & $1.5(0.9 ; 1.9)$ & $2.3(1.5 ; 2.8)$ \\
\hline$\geq 17$ year & 6 & 31.6 & 55 & 53.4 & 118 & 69.8 & 1.0 & 1.0 \\
\hline \multicolumn{9}{|c|}{ First intercourse ${ }^{* * *}$} \\
\hline$<1$ month & 7 & 36.8 & 14 & 13.7 & 25 & 14.8 & $2.7(1.2 ; 4.6)$ & $2.5(1.2 ; 4.2)$ \\
\hline$\geq 1$ month & 12 & 63.2 & 88 & 86.3 & 144 & 85.2 & 1.0 & 1.0 \\
\hline \multicolumn{9}{|c|}{ Sex with commercial sex workers } \\
\hline Yes & 6 & 31.6 & 15 & 14.7 & 17 & 10.1 & $2.2(0.9 ; 40)$ & $3.1(1.3 ; 5.8)$ \\
\hline No & 13 & 68.4 & 87 & 85.3 & 152 & 89.9 & 1.0 & 1.0 \\
\hline \multicolumn{9}{|c|}{ Exchanging sex for money } \\
\hline Yes & 2 & 10.5 & 7 & 6.7 & 2 & 1.2 & $1.6(0.3 ; 5.7)$ & $8.9(1.3 ; 39)$ \\
\hline No & 17 & 89.5 & 97 & 93.3 & 167 & 98.8 & 1.0 & 1.0 \\
\hline \multicolumn{9}{|c|}{ Same-sex practices } \\
\hline Yes & 5 & 26.3 & 7 & 6.7 & 7 & 4.1 & $3.9(1.4 ; 8.4)$ & $6.4(2.2 ; 13)$ \\
\hline No & 14 & 73.7 & 97 & 93.3 & 162 & 95.9 & 1.0 & 1.0 \\
\hline \multicolumn{9}{|c|}{ Casual sex partners } \\
\hline Yes & 13 & 68.4 & 69 & 67.0 & 41 & 24.3 & $1.0(0.6 ; 1.3)$ & $2.8(1.8 ; 3.5)$ \\
\hline No & 6 & 31.6 & 34 & 33.0 & 128 & 75.7 & 1.0 & 1.0 \\
\hline \multicolumn{9}{|c|}{ Concurrent partners } \\
\hline Yes & 13 & 68.4 & 42 & 41.6 & 11 & 6.6 & $1.6(1.0 ; 2.1)$ & $10.4(6.2 ; 13)$ \\
\hline No & 6 & 31.6 & 59 & 58.4 & 156 & 93.4 & 1.0 & 1.0 \\
\hline \multicolumn{9}{|l|}{ Condom use } \\
\hline Inconsistent & 14 & 73.7 & 65 & 63.1 & 95 & 57.2 & $1.2(0.8 ; 1.4)$ & $1.3(0.9 ; 1.6)$ \\
\hline Consistent & 5 & 26.3 & 38 & 36.9 & 71 & 42.8 & 1.0 & 1.0 \\
\hline \multicolumn{9}{|c|}{ Antibodies against HSV-2 } \\
\hline Yes & 4 & 21.1 & 4 & 3.8 & 4 & 2.4 & $5.5(1.5 ; 14.2)$ & $8.8(2.4 ; 22)$ \\
\hline No & 15 & 78.9 & 100 & 96.2 & 165 & 97.6 & 1.0 & 1.0 \\
\hline
\end{tabular}

\section{DISCUSSION}

It has been pointed out that many studies of bridge populations and core groups define these concepts purely in behavioral terms without relating them to STI prevalence and incidence. ${ }^{2}$ The assumption behind this approach is that high-risk behaviors are strongly correlated with STIs. Nevertheless, this assumption depends on STI prevalence and incidence estimations in the population studied. The core group in the present study was defined on a behavioral basis and, at the same time, HSV-2 seroprevalence was estimated as a biological marker of sexual behavior. 
Table 3. Relationship between "level of STI risk" and sociodemographic characteristics, sexual behavior and HSV-2 seroprevalence in female students. Morelos, Mexico, 2001-2003.

\begin{tabular}{|c|c|c|c|c|c|c|c|c|}
\hline \multirow{2}{*}{ Characteristic } & \multicolumn{2}{|c|}{ High-risk } & \multicolumn{2}{|c|}{ Medium-risk } & \multicolumn{2}{|c|}{ Low-risk } & \multirow{2}{*}{$\begin{array}{l}\text { High vs. medium* } \\
\text { OR }(95 \% \mathrm{Cl})\end{array}$} & \multirow{2}{*}{$\begin{array}{l}\text { High vs. low** } \\
\text { OR }(95 \% \mathrm{Cl})\end{array}$} \\
\hline & $\mathrm{N}$ & $\%$ & $\mathrm{~N}$ & $\%$ & $\mathrm{~N}$ & $\%$ & & \\
\hline \multicolumn{9}{|l|}{ Age (years) } \\
\hline$\geq 23$ & 2 & 20.0 & 18 & 25.0 & 96 & 28.8 & $1.2(0.3 ; 3.0)$ & $0.9(0.2 ; 2.4)$ \\
\hline $21-22$ & 5 & 50.0 & 19 & 26.4 & 104 & 31.2 & $2.0(0.7 ; 3.2)$ & $1.6(0.6 ; 2.6)$ \\
\hline $18-20$ & 3 & 30.0 & 35 & 48.6 & 133 & 39.9 & 1.0 & 1.0 \\
\hline \multicolumn{9}{|l|}{ Smoking } \\
\hline Sometimes & 9 & 90.0 & 51 & 68.9 & 165 & 49.3 & $1.3(0.8 ; 1.4)$ & $1.8(1.1 ; 2.0)$ \\
\hline Never & 1 & 10.0 & 23 & 31.1 & 170 & 50.7 & 1.0 & 1.0 \\
\hline \multicolumn{9}{|l|}{ Alcohol } \\
\hline High & 6 & 60.0 & 16 & 21.6 & 20 & 6.0 & $2.8(1.3 ; 4.0)$ & $10.0(4.7 ; 14.2)$ \\
\hline Medium/low & 4 & 40.0 & 58 & 78.4 & 315 & 94.0 & 1.0 & 1.0 \\
\hline \multicolumn{9}{|c|}{ First sexual relationship } \\
\hline 10-16 years & 2 & 20.0 & 20 & 27.4 & 48 & 14.4 & $0.7(0.2 ; 2.1)$ & $1.4(0.3 ; 3.8)$ \\
\hline$\geq 17$ year & 8 & 80.0 & 53 & 72.6 & 285 & 85.6 & 1.0 & 1.0 \\
\hline \multicolumn{9}{|c|}{ First intercourse $\mathrm{e}^{* * *}$} \\
\hline$<1$ month & 0 & 0.0 & 4 & 5.4 & 8 & 2.4 & - & - \\
\hline$\geq 1$ month & 10 & 100.0 & 70 & 94.6 & 326 & 97.6 & & \\
\hline \multicolumn{9}{|c|}{ Sex with commercial sex workers } \\
\hline Yes & 0 & 0.0 & 0 & 0.0 & 1 & 0.3 & - & - \\
\hline No & 10 & 100.0 & 74 & 100.0 & 333 & 99.7 & & \\
\hline \multicolumn{9}{|c|}{ Exchanging sex for money } \\
\hline Yes & 0 & 0.0 & 2 & 2.7 & 1 & 0.3 & - & - \\
\hline No & 10 & 100.0 & 72 & 97.3 & 334 & 99.7 & & \\
\hline \multicolumn{9}{|c|}{ Same-sex practices } \\
\hline Yes & 1 & 10.0 & 2 & 2.7 & 11 & 3.3 & $3.7(0.3 ; 21.3)$ & $3.0(0.4 ; 14)$ \\
\hline No & 9 & 90.0 & 72 & 97.3 & 324 & 96.7 & 1.0 & 1.0 \\
\hline \multicolumn{9}{|c|}{ Casual sex partners } \\
\hline Yes & 9 & 90.0 & 20 & 27.0 & 32 & 9.6 & $3.3(1.9 ; 3.7)$ & $9.4(5.5 ; 10)$ \\
\hline No & 1 & 10.0 & 54 & 73.0 & 303 & 90.4 & 1.0 & 1.0 \\
\hline \multicolumn{9}{|c|}{ Concurrent partners } \\
\hline Yes & 3 & 30.0 & 31 & 42.5 & 12 & 6.6 & $0.7(0.2 ; 1.5)$ & $8.4(2.5 ; 18)$ \\
\hline No & 7 & 70.0 & 42 & 57.5 & 323 & 93.4 & 1.0 & 1.0 \\
\hline \multicolumn{9}{|l|}{ Condom use } \\
\hline Inconsistent & 8 & 80.0 & 53 & 71.6 & 199 & 57.2 & $1.1(0.6 ; 1.3)$ & $1.3(0.8 ; 1.6)$ \\
\hline Consistent & 2 & 20.0 & 21 & 28.4 & 129 & 42.8 & 1.0 & 1.0 \\
\hline \multicolumn{9}{|c|}{ Antibodies against HSV-2 } \\
\hline Yes & 0 & 0.0 & 6 & 8.1 & 16 & 4.8 & - & - \\
\hline No & 10 & 100.0 & 68 & 91.9 & 319 & 95.2 & & \\
\hline
\end{tabular}

* High-risk versus medium-risk groups

** High-risk versus low-risk groups

*** Time since subjects had known their first sex partner

As expected, there was a significant correlation between HSV-2 seroprevalence and the "level of STI risk" variable, as it was seen a decreasing trend in seroprevalence from the high-risk (core group) to the low-risk group. However, after stratified by gender, the seroprevalence among men was $21.1 \%, 3.8 \%$ and
$2.4 \%$, respectively. Unexpectedly, among women, no seroprevalent cases were found in the really small high-risk group $(\mathrm{N}=10)$, but $8.1 \%$ and $4.8 \%$ prevalences were seen in medium- and low-risk groups, respectively. These results suggest an existing core group which is almost exclusively male. 
Table 4. Polytomous logistic regression regarding sociodemographic characteristics, sexual behavior and HSV-2 seroprevalence in college students by gender. Morelos, Mexico, 2001-2003.

\begin{tabular}{|c|c|c|c|c|}
\hline \multirow[t]{2}{*}{$\begin{array}{l}\text { Gender/ } \\
\text { Characteristic }\end{array}$} & \multicolumn{2}{|c|}{$\begin{array}{l}\text { High- versus } \\
\text { medium-risk } \\
\text { group }\end{array}$} & \multicolumn{2}{|c|}{$\begin{array}{l}\text { High- versus } \\
\text { low-risk group }\end{array}$} \\
\hline & $\operatorname{Exp}(\beta)$ & $95 \% \mathrm{Cl}$ & $\operatorname{Exp}(\beta)$ & $95 \% \mathrm{Cl}$ \\
\hline \multicolumn{5}{|l|}{ Women } \\
\hline \multicolumn{5}{|l|}{ Smoking } \\
\hline Yes & 1.2 & $0.5 ; 1.4$ & 1.7 & $0.7 ; 2.0$ \\
\hline \multicolumn{5}{|l|}{ Alcohol } \\
\hline High & 3.0 & $1.3 ; 4.2$ & 9.5 & $3.5 ; 14.5$ \\
\hline \multicolumn{5}{|c|}{ Casual sex partners } \\
\hline Yes & 3.4 & $2.1 ; 3.7$ & 9.3 & $4.9 ; 10.3$ \\
\hline \multicolumn{5}{|c|}{ Concurrent partners } \\
\hline Yes & 0.5 & $0.1 ; 1.3$ & 4.7 & $0.9 ; 15.3$ \\
\hline \multicolumn{5}{|l|}{ Men } \\
\hline \multicolumn{5}{|l|}{ Smoking } \\
\hline Yes & 1.6 & $1.3 ; 1.7$ & 2.1 & $1.6 ; 2.1$ \\
\hline \multicolumn{5}{|c|}{ First sexual relationship } \\
\hline $\begin{array}{l}10-16 \\
\text { years }\end{array}$ & 1.5 & $0.8 ; 1.9$ & 2.0 & $1.0 ; 2.8$ \\
\hline \multicolumn{5}{|c|}{ First intercourse* } \\
\hline$<1$ month & 2.9 & $1.0 ; 5.4$ & 2.9 & $1.0 ; 5.2$ \\
\hline \multicolumn{5}{|l|}{ Same-sex } \\
\hline Yes & 4.5 & $1.4 ; 9.7$ & 7.9 & $2.1 ; 17.4$ \\
\hline \multicolumn{5}{|c|}{ Concurrent partners } \\
\hline Yes & 1.7 & $0.9 ; 2.1$ & 10.2 & $5.2 ; 13.5$ \\
\hline \multicolumn{5}{|c|}{ Antibodies against HSV-2 } \\
\hline Positive & 10.7 & $1.7 ; 23.0$ & 13.7 & $1.7 ; 35.3$ \\
\hline
\end{tabular}

* Time since subjects had known their first sex partner

Gender differences in the core groups were supported by findings which characterized the study population. Men had a higher number of sex partners, had their first sexual intercourse earlier and consumed more alcohol and drugs than women. Likewise, men had more sex with sex workers, exchanging sex for money, casual sex partners, and concurrent partners than women. These results are consistent with the size of the male core group which was significantly larger than the female one $(6.5 \%$ versus $2.4 \%, \mathrm{p}=0.012)$.

These findings suggest existing contextual characteristics in the population studied that affect their sexual behavior. In Mexico, cultural concepts of sexuality are determined by gender differences. According to Carrier, ${ }^{5}$ the Mexican mestizo culture places a high value on manliness. As a consequence, there is a clear delimitation of male and female roles. Males are expected to be dominant and independent and females to be submis- sive and dependent. The hypermasculine ideal model of manliness is referred as machismo. Prior to Carrier, $\mathrm{Paz}^{14}$ had already described cultural differences in both male and female behavior, and more recently GonzálezBlock \& Liguori ${ }^{10}$ analyzed the cultural characteristic of manliness in the context of the HIV/AIDS epidemic in Mexico. The findings of the present study show that gender differences regarding sexual behavior in the population studied is still a major issue determined by the cultural context of sexuality.

The core group approach help identifying those at higher STI risk and their behavioral characteristics. When this group is compared to medium- and low-risk groups, as a product of a multinomial analysis among men, the risk of smoking was significantly higher in those in the core group. Villatoro et $\mathrm{al}^{20}$ have found a significant association between smoking and the consumption of alcohol and other drugs such as marijuana and cocaine in high school and college students in Mexico, and they have also found that smoking predicts the consumption of other drugs. This observation is consistent with the findings in the present study where all those in the highrisk group had a history of cocaine consumption.

Indicators of sexual behavior such as age at first sexual intercourse and how long their relationship with their first sex partner lasted are indicators of periods of exposure to be included in the high-risk male group. In the former case, those who had had sexual intercourse before the age of 17 were more likely to be in the highrisk group. This can be explained by the fact that those who have sexual intercourse at an early age are more likely to have a higher number of sexual partners and, as a result, longer periods of exposure compared to those individuals who start their sexual lives after the age of 17. In fact, those in the high-risk group had, on average, 5.9 lifetime sex partners versus 2.4 partners in the low-risk group ( $<<0.001$ by Kruskal-Wallis test). On the other hand, those who delayed sexual activity longer with their first sexual partner ( $\geq 1$ month) were less likely to be in the high-risk group (compared with medium- and low-risk groups). The longer to start their first sexual relationship, the less likely they are to have multiple sex partners (those in this group had on average 3.1 lifetime sex partners versus 5.2 partners in the comparison group, $\mathrm{p}<0.001)$. Indicators of high-risk sexual behavior among men, such as same-sex practices, history of concurrent partners and HSV-2 seroprevalence were factors strongly associated with the high-risk group (core group) compared to the medium- and low-risk groups.

Women's behavior was significantly different. First, no cases of HSV-2 infection were found in the female core group. Secondly, the size of this high-risk group was much smaller than the corresponding male group. Thirdly, the only two behavioral variables that were independently associated with the high-risk group 
were high alcohol consumption and history of casual partners. The main question is: why didn't women in the core group have any cases of HSV-2 infection? It may be that women engaging in high-risk behavior took more preventive measures against STI than men. For instance, nine out of the ten women in the core group had casual partners. Six of them reported consistent condom use with casual partners; two reported occasional use and only one did not use condoms. This suggests there could be gender differences regarding the construction of the core group in terms of sexual behavior. However, the quantitative information gathered in this study does not allow to supporting this hypothesis. Further qualitative studies using in-depth interviews or focal groups could provide more input to better characterize gender differences in the construction of core groups.
In conclusion, variables such as the number of sex partners during the last year and cocaine use were useful behavioral indicators to construct the core group in the study population. This strategy allowed to identifying not only those at higher risk for STI and their behavioral characteristics but also major gender differences that may exist in the construction of these core groups.

\section{ACKNOWLEDGEMENTS}

To university authorities from Universidad Autónoma del Estado de Morelos, of following schools: Administration, Biology, Education, Law, Medicine, Pharmacy and Psychology, who gave us permission to approach potential participants. 


\section{REFERENCES}

1. Anderson RM, May RM. Epidemiological parameters of HIV transmission. Nature. 1988;333(6173):514-9.

2. Aral SO. Behavioral aspects of sexually transmitted diseases. Core group and bridge populations. Sex Transm Dis. 2000;27(6):327-8.

3. Bernstein KT, Curriero FC, Jennings JM, Olthoff $G$, Erbelding EJ, Zenilman J. Defining core gonorrhea transmission utilizing spatial data. Am / Epidemiol. 2004;160(1):51-8.

4. Borooah VK. Logit and probit: ordered and multinomial models. Thousand Oaks, CA: Sage; 2002.

5. Carrier JM. Cultural factors affecting urban Mexican male homosexual behavior. Arch Sex Behavior. 1976;5(2):103-24.

6. Centers for Disease Control. Number of sex partners and potential risk of sexual exposure to human immunodeficiency virus. MMWR Morb Mortal Wkly Rep. 1988;37(37):565-8.

7. Conde-Glez CJ, Juárez-Figueroa L, Uribe-Salas F, Hernández-Nevárez P, Scott Schmid D, Calderon E, et al. Analysis of herpes simplex virus 1 and 2 infection in women with high risk sexual behavior in Mexico. Int J Epidemiol. 1999;28(3):571-6.

8. Cowan FM, Johnson AM, Ashley R, Corey L, Mindel A. Antibody to herpes simplex virus type 2 as serological marker of sexual lifestyle in populations. BMJ. 1994;309(6965):1325-9.

9. Flom PL, Friedman SR, Kottiri BJ, Neaigus A, Curtis $R$, Des Jarlais DC, et al. Stigmatized drug use, sexual partner concurrency, and other sex risk network and behavior characteristics of 18-24 year old youth in a high-risk neighborhood. Sex Transm Dis. $2001 ; 28(10): 598-606$.

10. González-Block MA, Liguori AL. SIDA y estratos sociales en México: la importancia del bisexualismo. Salud Publica Mex. 1990;32(1):26-37.

11. Hser YI, Chou CP, Hoffman V, Anglin MD. Cocaine use and high-risk sexual behavior among STD clinic patients. Sex Transm Dis. 1999;26(2):82-6.

12. Nagelkerke NJD, Brunham RC, Moses S, Plummer FA. Estimating the effective rate of sex partner change in a population from individuals with sexually transmitted diseases. Sex Transm Dis. 1994;21(4):226-30.
13. Nelson KE, Williams CM, Graham NMH. Infectious disease epidemiology. [S.I.]: Aspen; 2001.

14. Paz O. El laberinto de la soledad. México: Fondo de Cultura Económica; 1973.

15. Rothenberg RB, Potterat JJ, Woodhouse DE. Personal risk taking and the spread of disease: beyond the core groups. J Infect Dis. 1996;174(Suppl 2):S144-9.

16. Sánchez-Alemán MA, Conde-Glez CJ, Gayet C, García-Cisneros S, Uribe-Salas F. Sexual behavior and herpes simplex virus 2 infection in college students. Arch Med Res. 2005;36(5):574-80.

17. Sánchez-Martínez D, Pellett P. Expression of HSV-1 and HSV-2 glycoprotein $\mathrm{G}$ in insect cells by using a novel baculovirus expression vector. Virology. 1991;182(1):229-38.

18. Thomas JC, Tucker MJ. The development and use of the concept of a sexually transmitted disease core. I Infect Dis. 1996;174(Suppl 2):S134-43.

19. Uribe-Salas F, Conde-Gelz CJ, Juárez-Figueroa L, Hernández-Castellanos A. Socio-demographic characteristics and sex practices related to herpes simplex virus type 2 infection in Mexican and Central American female sex workers. Epidemiol Infect. 2003;131(2):859-65.

20. Villatoro JA, Medina-Mora ME, Juárez F, Rojas E, Carreño S, Berenzon S. Drug use pathways among high school students of Mexico. Addiction. 1998;93(10):1577-88.

21. Willis LA. Tapping the core: behavioral characteristics of the low-income, African-American Male Core Group. Soc Theory Health. 2007;5(3):245-66.

22. World Health Organization. Guidelines for controlling and monitoring the tobacco epidemic. Geneva; 1998.

23. Yorke JA, Hethcote HW, Nold A. Dynamics and control of the transmission of gonorrohea. Sex Transm Dis. 1978;5(2):51-6.

24. Zamilpa-Mejía LG, Uribe-Salas F, Juárez-Figueroa L, Calderón-Jaimes E, Conde-González CJ. Prevalencia y factores asociados con sífilis y herpes genital en dos grupos de población femenina. Salud Publica Mex. 2003;45(supl 5):S617-23.

25. Zhang J, Yu KF. What's the relative risk? A method of correcting the odds ratio in cohort studies of common outcomes. JAMA. 1998;280(19):1690-1. 